\title{
Distribution and aggregation process of Cd in Jiaozhou Bay
}

\author{
Dongfang Yang ${ }^{1,2,3, a}$, Sixi Zhu ${ }^{1,2}$, Fengyou Wang ${ }^{1,2, b}$, Xiuqin Yang ${ }^{1,2}$ and \\ Xiaoli Zhao ${ }^{1,2}$ \\ ${ }^{1}$ Research Center for Karst Wetland Ecology, Guizhou Minzu University, Guiyang 550025, China; \\ ${ }^{2}$ College of Chemistry and Environmental Science, Guizhou Minzu University, Guiyang 550025, \\ China; \\ ${ }^{3}$ North China Sea Environmental Monitoring Center, SOA, Qingdao 266033, China. \\ adfyang_dfyang@126.com, ${ }^{b}$ corresponding author:wangfy2001@yahoo.com.cn
}

Keywords: Cd, Bottom waters, Distribution, Aggregation process, Jiaozhou Bay.

\begin{abstract}
This paper analyzed the vertical and seasonal distribution of Cd in Jiaozhou Bay bottom waters in 1983. Results showed that Cd contents ranged from $0.13-0.53 \mu \mathrm{g} \mathrm{L}^{-1}$, indicated that the pollution level of Cd in Jiaozhou Bay was very low in the early stage of reform and opening-up. Cd contents in surface waters were in orders of spring $<$ summer $<$ autumn, while for bottom waters were summer $<$ spring $<$ autumn. The distributions of Cd in surface and bottom water were reverse before the wet season, while for wet season were consistent. River discharge, marine terminals, island head, and overland runoff were the major sources of $\mathrm{Cd}$. There were always high value regions around Site H35 in the bay mouth in different seasons, which were determined by the high flow rate was high in the bay mouth, indicated that there was an aggregation process by means of the movement of the water body.
\end{abstract}

\section{Introduction}

Cd is one of the critical heavy metal which has been widely used in both agriculture and industry. Due to the toxic and harmful to human beings as well as the ecological environment, Cd pollution has been one of the serious environmental issue in the world. Ocean is the sink of various pollutants, particularly the coastal area has long been suffering from various pollutants including Cd [1-7]. Understanding the pollution level and transfer process in coastal area is essential to environment protection as well as ecological remediation. Based on the investigation data on Cd in Jiaozhou Bay, Shandong Province, eastern China in 1983, this paper analyzed the content and transfer process of $\mathrm{Cd}$, as well as provided basic information of Cd pollution level in the early stage of reform and opening-up.

\section{Study area and data source}

Jiaozhou Bay $\left(35^{\circ} 55^{\prime}-36^{\circ} 18^{\prime} \mathrm{N}, 120^{\circ} 04^{\prime}-120^{\circ} 23^{\prime} \mathrm{E}\right)$ is located in the south of Shandong Peninsula, eastern China (Fig. 1). It is a semi-closed bay, whose total area, bay mouth width, and average water depth are $446 \mathrm{~km}^{2}, 2.5 \mathrm{~km}$, and $7 \mathrm{~m}$ respectively. Big cities of Qingdao, Jiaozhou and Jiaonan are located inn the east, north and west of the bay, and the bay mouth is connected with the Yellow Sea. This bay has more than ten inflow rivers, such as Dagu River, Yang River, Haibo River, Licun River and Loushan River, whose hydrology is showing significant seasonal features [8-9].

The data was provided by North China Sea Environmental Monitoring Center, State Ocean Administration. The investigation on Cd in nine sampling sites (H34, H35, H36, H37, H38, H39, H40, H41 and H82) was carried on in May, September and October 1983. The measurement of Cd in water samples was following by Chinese Specification for Marine Monitoring [10]. 


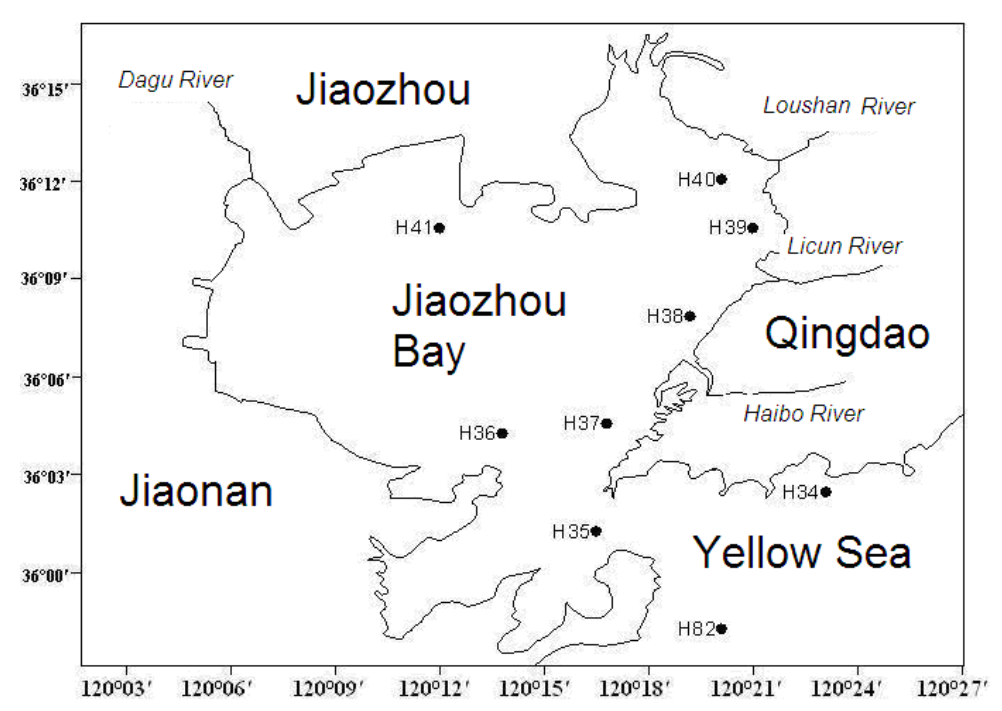

Fig.1 Geographic location and sampling sites of Jiaozhou Bay

\section{Cd contents and pollution levels}

Cd contents in bottom waters in the 9 sampling sites in May, September, and October ranged from $0.10-0.15 \mu \mathrm{g} \mathrm{L} \mathrm{L}^{-1}, 0.67-2.00 \mu \mathrm{g} \mathrm{L} \mathrm{L}^{-1}$, and $0.03-2.00 \mu \mathrm{g} \mathrm{L}^{-1}$, respectively, both of which were confirmed with Grade I (1.00 $\left.\mathrm{g} \mathrm{L}^{-1}\right)$ or Grade Grade II $\left(5.00 \mu \mathrm{g} \mathrm{L}^{-1}\right)$ in according to Chinese Sea Water Quality Standard (GB 3097-1997). Cd was originally transferred to the surface waters, and then was transferred from the surface waters to the bottom waters. The changes of Cd contents was determined by the dilution effect of the vertical water body [11]. In generally, Cd contents were very low in Jiaozhou Bay, especially in May, indicated that the pollution level of Cd in Jiaozhou Bay was very low in the early stage of reform and opening-up.

Table 1 Cr contents and pollution levels in bottom water in Jiaozhou Bay in 1983

\begin{tabular}{|c|c|c|c|}
\hline Time & May & September & October \\
\hline Concentration/ug L ${ }^{-1}$ & 0.10 to 0.15 & 0.67 to 2.00 & 0.03 to 2.00 \\
\hline Grade & I & I and II & I and II \\
\hline
\end{tabular}

\section{Distributions and sources of Cd}

The horizontal distributions of Cd in bottom waters in Jiaozhou Bay in May, September and October 1983 were showed in Fig. 2, Fig. 3 and Fig. 4, respectively. In May, The highest value of Cd contents was occurred in Site H37 $\left(0.15 \mu \mathrm{g} \mathrm{L}{ }^{-1}\right)$ in the east of the bay mouth, while low values were occurred in the bay mouth $\left(0.11 \mu \mathrm{g} \mathrm{L}^{-1}\right)$. Cr contents were decreasing from the east of the bay mouth to the west of the bay mouth (Fig. 2). A relative high value was also occurred in Site H35 in the bay mouth $\left(0.14 \mu \mathrm{g} \mathrm{L}^{-1}\right)$. The contour lines were forming a series of semi- concentric circles, and were decreasing from the high value center to external waters (Fig. 2). In September, The highest value of Cr contents was occurred in Site H34 $\left(2.00 \mu \mathrm{g} \mathrm{L}^{-1}\right)$ in coastal waters in the east of the bay, while low values were occurred in the south of the bay $\left(0.67 \mu \mathrm{g} \mathrm{L}^{-1}\right)$. The contour lines were forming a series of semi- concentric circles, and were decreasing from the high value center to south of the bay (Fig. 3). A relative high value was occurred in Site H 35 in the bay mouth (1.63 $\mu \mathrm{g}$ $\mathrm{L}^{-1}$ ), and the contents were decreasing from the high value center to the west of the bay (Fig. 3). In October, the highest value was occurred in Site H35 in the bay mouth $\left(2.00 \mu \mathrm{g} \mathrm{L}^{-1}\right)$. The contour lines were forming a series of semi-concentric circles, which were decreasing from the high value center the northwest of the bay, as well as to the southeast of the external water outside the bay mouth (Fig. 4). In according to the distributions, it could be defined that there were four major sources of $\mathrm{Cd}$ in this bay. In May, Cd in coastal waters within the bay was mainly sourced from marine terminals, while in coastal water outside the bay mouth was mainly sourced from overland 
runoff. In September, Cd was mainly from the transported of the island head. In October, river discharge was responsible for the inputs of $\mathrm{Cd}$ in waters in the northeast in the bay, and marine terminals was responsible for the inputs of $\mathrm{Cd}$ in coastal waters in the north of the bay. The source strength of river discharge, marine terminals, island head, and overland runoff, could reach $0.80 \mu \mathrm{g}$ $\mathrm{L}^{-1}, 1.50 \mu \mathrm{g} \mathrm{L}{ }^{-1}, 3.33 \mu \mathrm{g} \mathrm{L}^{-1}$, and $0.41 \mu \mathrm{g} \mathrm{L}^{-1}$, respectively.

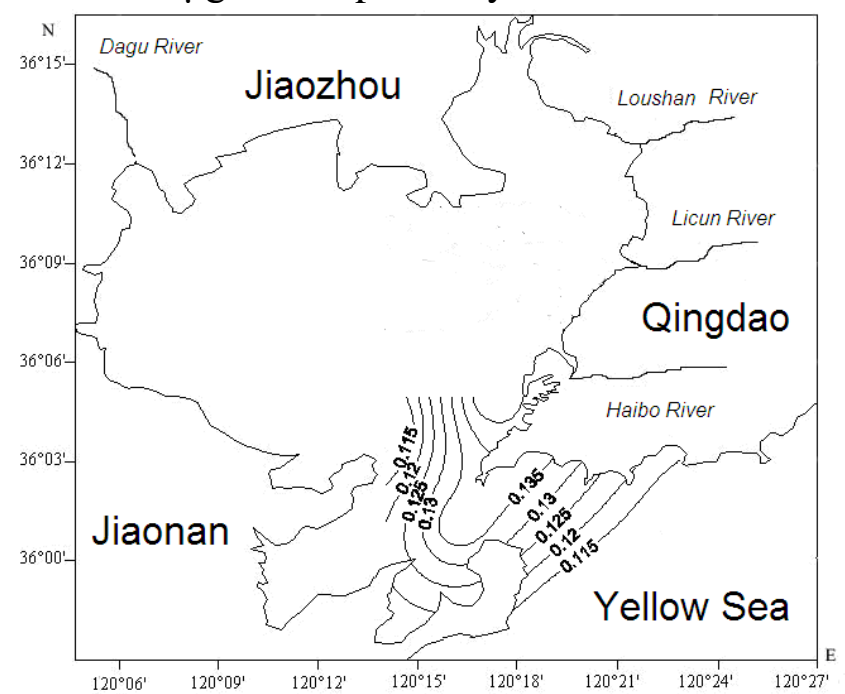

Fig. 2 Distributions of Cd in bottom waters in Jiaozhou Bay in May $\left(\mu \mathrm{g} \mathrm{L}^{-1}\right)$

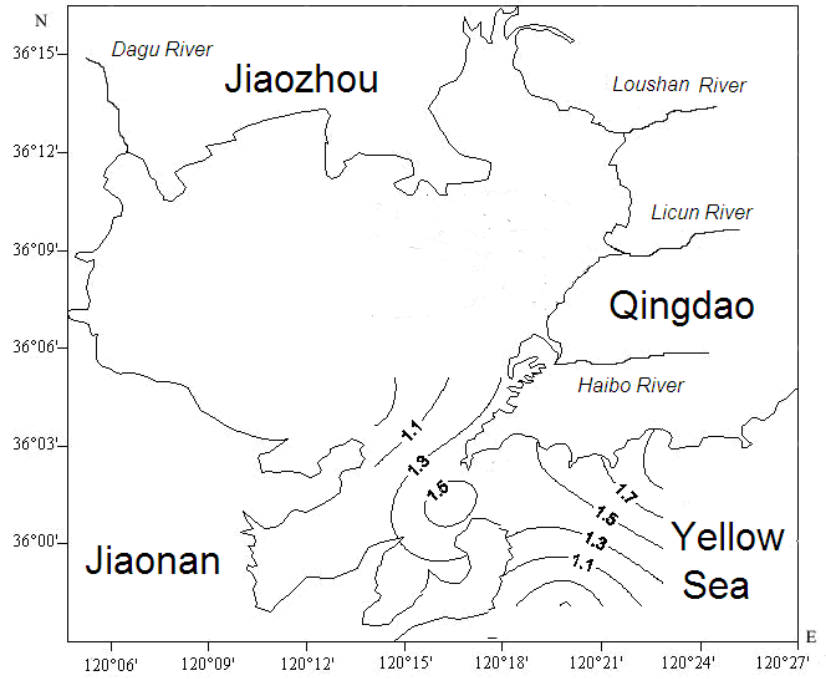

Fig. 3 Distributions of Cd in bottom waters in Jiaozhou Bay in September $\left(\mu \mathrm{g} \mathrm{L}^{-1}\right)$

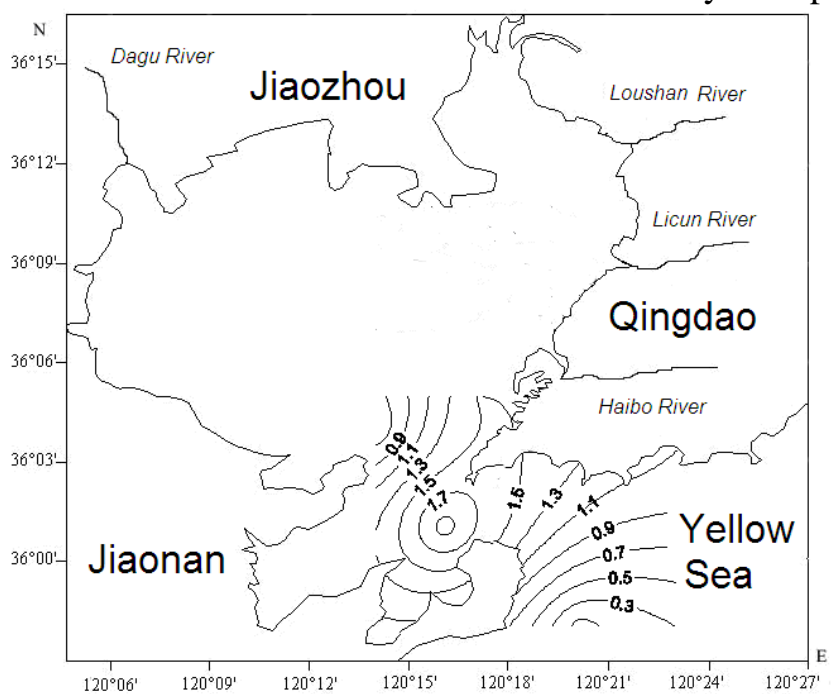

Fig. 4 Distributions of Cd in bottom waters in Jiaozhou Bay in October $\left(\mu \mathrm{g} \mathrm{L}^{-1}\right)$ 


\section{Aggregation process of $\mathrm{Cr}$ in bottom waters}

Jiaozhou Bay is a semi-closed bay, whose east-west width and north-south length are $27.8 \mathrm{~km}$ and $33.3 \mathrm{~km}$, respectively. There are two secondary bay mouths namely interior bay mouth and exterior bay mouth, and there is a deep $(40 \mathrm{~m})$ water channel in along the bay mouths. The tidal current in the water channel in the bay mouth is very strong, the amplitude of tidal current of $\mathrm{M}_{2}$ is as high as $1 \mathrm{~m} \mathrm{~s}^{-1}$, and the instantaneous velocity of the flow in this water channel during the spring tide is $2.01 \mathrm{~m} \mathrm{~s}^{-1}$ [12]. No matter in different areas (northeast in the bay, coastal waters in the east of the bay, the bay mouth, and coastal water in the east outside the bay mouth), there were always high value regions around Site H35 located in the bay mouth in May, September, and October, whose highest values were $0.14 \mu \mathrm{g} \mathrm{L}^{-1}, 1.63 \mu \mathrm{g} \mathrm{L}^{-1}$, and $2.00 \mu \mathrm{g} \mathrm{L}^{-1}$, respectively. These high value regions in bottom waters were determined by the high flow rate was high in the bay mouth, indicated that there was an aggregation process by means of the movement of the water body.

\section{Conclusions}

Cd contents were very low in Jiaozhou Bay, especially in May, indicated that the pollution level of Cd in Jiaozhou Bay was very low in the early stage of reform and opening-up. River discharge, marine terminals, island head, and overland runoff were the major sources of $\mathrm{Cd}$, whose source strength could reach $0.80 \mu \mathrm{g} \mathrm{L}^{-1}, 1.50 \mu \mathrm{g} \mathrm{L} \mathrm{L}^{-1}, 3.33 \mu \mathrm{g} \mathrm{L}{ }^{-1}$, and $0.41 \mu \mathrm{g} \mathrm{L} \mathrm{L}^{-1}$, respectively. There were always high value regions around Site H35 located in the bay mouth in different seasons, which were determined by the high flow rate was high in the bay mouth, indicated that there was an aggregation process by means of the movement of the water body.

\section{Acknowledgement}

This research was sponsored by Research Projects of Guizhou Nationalities University ([2014]02), Research Projects of Guizhou Province Ministry of Education (KY [2014] 266), Research Projects of Guizhou Province Ministry of Science and Technology (LH [2014] 7376), and Director Fund projects of North China Sea Environmental Monitoring Center, State Ocean Administration (05EMC16).

\section{References}

[1] Yang DF and Miao ZQ: Marine Bay Ecology (I): Beijing, Ocean Precess, (2010), p. 1-320. (in Chinese)

[2] Yang DF and Miao ZQ: Marine Bay Ecology (II): Beijing, Ocean Precess, (2010), p. 1-330. (in Chinese)

[3] Yang DF, Chen Y, Wang H, et al.: Coastal Engineering, Vol. 29 (2010), p. 73-82. (in Chinese)

[4] Yang DF, Chen Y, Chang YX, et al.: Coastal Engineering, Vol. 32 (2013), p. 68-78. (in Chinese)

[5] Yang DF, Zhu SX, Wang FY, et al.: Applied Mechanics and Materials, Vol. 644-650 (2014), p. 5325-5328.

[6] Yang DF, Wang FY, Wu YF, et al.: Applied Mechanics and Materials, Vol. 644-650 (2014), p. 5329-5312.

[7] Yang DF, Chen ST, Li BL, et al.:Proceedings of the 2015 international symposium on computers and informatics, (2015), p. 2667-2674.

[8] Yang D F, Chen Y, Gao Z H, Zhang J, et al.:Chin. J. Oceanol. Limnol., Vol. 23(2005): 72-90.

[9] Yang DF, Wang F, Gao ZH, et al.: Marine Science, Vol. 28 (2004), p. 71-74. (in Chinese)

[10] State Ocean Administration. The specification for marine monitoring: Beijing, Ocean Precess, (1991).

[11]Yang DF, Wang FY, He HZ, et al.: Proceedings of the 2015 international symposium on computers and informatics, (2015): 2655-2660.

[12]Lv XG, Zhao C, Xia CY.: Acta Oceanologica Sinica, Vol. 32 (2010), p. 20-30. (in Chinese) 